\title{
Glucocorticoids Stimulate Rabbit Proximal Convoluted Tubule Acidification
}

\author{
Michel Baum and Raymond Quigley \\ Departments of Pediatrics and Medicine, The University of Texas Southwestern Medical Center at Dallas, Dallas, Texas 75235-9063
}

\begin{abstract}
Glucocorticoids have an important role in renal acidification; however, a direct effect of glucocorticoids on proximal convoluted tubule (PCT) acidification has not been directly demonstrated. In the present in vitro microperfusion study PCT from animals receiving dexamethasone $(600 \mu \mathrm{g} / \mathrm{kg}$ twice daily for 2 d and $\mathbf{2} \mathrm{h}$ before killing) had a significantly higher rate of bicarbonate absorption than did controls $(92.0 \pm 13.3$ vs $59.9 \pm 3.2$ $\mathrm{pmol} / \mathrm{mm} \cdot \mathrm{min}, \boldsymbol{P}<\mathbf{0 . 0 1}$ ). To examine if glucocorticoids had a direct epithelial action, dexamethasone was added to the bath of PCT perfused in vitro. After $3 \mathrm{~h}$ of incubation in paired experiments $10^{-6} \mathrm{M}$ and $10^{-5} \mathrm{M}$ dexamethasone resulted in an $\sim 30 \%$ stimulation in the rate of bicarbonate absorption. $10^{-7}$ $M$ dexamethasone and $10^{-6} \mathrm{M}$ aldosterone had no effect on bicarbonate absorption. The stimulation of acidification by $10^{-5} \mathrm{M}$ dexamethasone was blocked by actinomycin $\mathrm{D}$ and cycloheximide. These data are consistent with a direct effect of glucocorticoids on PCT acidification, and this effect is dependent upon protein synthesis. (J. Clin. Invest. 1993. 91:110114.) Key words: proximal tubule $\bullet$ glucocorticoids • volume absorption • acidification $\bullet$ microperfusion
\end{abstract}

\section{Introduction}

Administration of glucocorticoids has been shown to increase acid production $(1,2)$, increase ammonia (1-5) and net acid excretion $(1,2,5)$, and increase plasma bicarbonate concentration $(1,3)$. Adrenalectomized animals have a decrease in net acid excretion $(5,6)$, and a decrease in net acid excretion upon acid loading $(2,6-8)$. However, there are no data which adequately assess the effect of pure glucocorticoid deficiency on renal net acid excretion or systemic acid-base equilibrium.

The majority of renal bicarbonate absorption occurs in the proximal tubule, where proton secretion is largely mediated by the $\mathrm{Na}^{+} / \mathrm{H}^{+}$antiporter (9). Previous studies have demonstrated that systemic administration of dexamethasone increases $\mathrm{Na}^{+} / \mathrm{H}^{+}$antiporter activity, whereas adrenalectomy did not produce a decrease in antiporter activity $(8,10,11)$. This effect of dexamethasone is caused by an increase in the $V_{\max }$ of the $\mathrm{Na}^{+} / \mathrm{H}^{+}$antiporter, with no change in the $K_{\mathrm{m}}$ for sodium (11).

Whereas these studies suggest that glucocorticoids may have a direct proximal tubular effect to stimulate acidification,

Address correspondence to Michel Baum, M.D., Department of Pediatrics, University of Texas Southwestern Medical Center, 5323 Harry Hines Boulevard, Dallas, Texas 75235-9063.

Received for publication 4 May 1992 and in revised form 27 July 1992.

J. Clin. Invest.

(C) The American Society for Clinical Investigation, Inc.

0021-9738/93/01/110/05 \$2.00

Volume 91, January 1993, 110-114 this has not been directly examined. In addition, glucocorticoids have systemic and hemodynamic effects which could affect proximal tubule transport independent of a direct hormonal effect on the proximal tubule epithelium. The purpose of the present in vitro microperfusion study was to examine if glucocorticoids stimulate proximal tubule acidification, and if there was a direct effect of glucocorticoids on the proximal tubule independent of potential systemic effects.

\section{Methods}

Midcortical and juxtamedullary rabbit proximal convoluted tubule (PCT) ${ }^{1}$ were perfused as previously described $(12,13)$. Briefly, kidneys from adult New Zealand White rabbits were cut in coronal slices. PCT were dissected in a cooled $\left(4^{\circ} \mathrm{C}\right)$ ultrafiltrate-like solution containing $115 \mathrm{mM} \mathrm{NaCl}, 25 \mathrm{mM} \mathrm{NaHCO}_{3}, 4 \mathrm{mM} \mathrm{Na}_{2} \mathrm{HPO}_{4}, 10 \mathrm{mM} \mathrm{Na}$

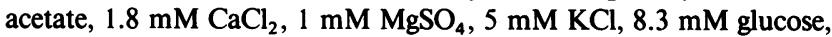
and $5 \mathrm{mM}$ alanine.

Tubules were perfused with the above ultrafiltrate-like solution and bathed in a similar solution containing $6 \mathrm{~g} / \mathrm{dl}$ albumin (Fraction V; Sigma Chemical Co., St. Louis, MO). The albumin was dialyzed against distilled water (Spectrapor Dialysis tubes with 12,000-14,000 MW cut off; Spectrum Medical Industries, Los Angeles, CA) for at least $48^{\circ}$ before addition of salts. All solutions were bubbled with $95 \%$ $\mathrm{O}_{2}$ and $5 \% \mathrm{CO}_{2}$ and had a $\mathrm{pH}$ of 7.4. The osmolality of the perfusate and bath were adjusted to 295 by the addition of $\mathrm{H}_{2} \mathrm{O}$ or $\mathrm{NaCl}$. All tubules were perfused at $\sim 10 \mathrm{nl} / \mathrm{min}$ at $38^{\circ} \mathrm{C}$ in a $1 \mathrm{ml}$ temperaturecontrolled bath. The bath fluid was changed at a rate of $0.5 \mathrm{ml} / \mathrm{min}$ to maintain a constant bath osmolality and $\mathrm{pH}$. The control collections began after a 90 -min equilibration period.

Net volume absorption $\left(\mathrm{J}_{\mathrm{V}}\right.$, in $\left.\mathrm{nl} / \mathrm{mm} \cdot \mathrm{min}\right)$ was measured as the difference between the perfusion $\left(\mathrm{V}_{\mathrm{O}}\right)$ and collection $\left(\mathrm{V}_{\mathrm{L}}\right)$ rates $(\mathrm{nl} /$ min) normalized per millimeter of tubular length (L). Exhaustively dialyzed [methoxy- ${ }^{3} \mathrm{H}$ ] inulin was added to the perfusate at a concentration of $50 \mu \mathrm{Ci} / \mathrm{ml}$ so that the perfusion rate could be calculated. The collection rate was measured with a $60-n l$ constant volume pipette. The length, in millimeters, was measured with an eyepiece micrometer.

Net total $\mathrm{CO}_{2}$ flux $\left(\mathrm{J}_{\mathrm{TCO} 2}, \mathrm{pmol} / \mathrm{mm} \cdot \mathrm{min}\right)$ was calculated according to the equation:

$J_{T C O_{2}}=\left(V_{o} C_{O}-V_{L} C_{L}\right) / L$,

where $C_{O}$ and $C_{L}$ represent the concentration of $T_{\mathrm{CO}_{2}}$ in the perfused and collected fluid, respectively. $\mathrm{T}_{\mathrm{CO} 2}$ measurements were performed using microcalorimetry (Picapnotherm, model GVI; World Precision Instruments, Inc., New Haven, CT).

The transepithelial potential difference (PD, in millivolts) was measured by using the perfusion pipette as the bridge into the tubular lumen. The perfusion and bath solutions were connected to the recording and reference calomel half-cells, respectively, via a bridge containing perfusion solution in series with a $3.6 \mathrm{M} \mathrm{KCl} / 0.9 \mathrm{M} \mathrm{KNO}_{3}$ agarose bridge. This arrangement avoided direct contact of $\mathrm{KCl} / \mathrm{KNO}_{3}$, agarose bridges with the solution that bathed the tubule. In addition, this arrangement eliminates the Donnan potential when the bath contains protein. The recording and reference calomel half-cells were connected to the high and low impedance side, respectively, of an electrometer (model 602; Keithley Instruments, Inc., Cleveland, $\mathrm{OH}$ ).

1. Abbreviations used in this paper: PCT, proximal convoluted tubule; $\mathrm{PD}$, potential difference. 
To examine if glucocorticoids affect PCT transport, animals in the experimental group received a subcutaneous injection of $600 \mu \mathrm{g} / \mathrm{kg}$ dexamethasone twice daily starting $48 \mathrm{~h}$ before study. They also received an injection in the morning $2 \mathrm{~h}$ before killing (total of five doses). The dexamethasone was dissolved in $150 \mathrm{mM} \mathrm{NaCl}$ and $2 \mathrm{mM}$ $\mathrm{K}_{2} \mathrm{HPO}_{4}(\mathrm{pH}=7.5)$. Control animals received equivalent doses of diluent. Blood and urine samples were collected for measurement of $\mathrm{pH}$ and bicarbonate concentration at the time of killing. PCT were then dissected and perfused in vitro to examine if in vivo administration of pharmacologic doses of glucocorticoids affected the PD and the rate of volume and bicarbonate absorption.

In studies designed to examine whether glucocorticoids had a direct effect on PCT transport, collections were made for measurement of volume absorption and bicarbonate transport in the control period. The bathing solution was then changed to one which contained $0 \mathrm{M}$, $10^{-7} \mathrm{M}, 10^{-6} \mathrm{M}$, or $10^{-5} \mathrm{M}$ dexamethasone. The rates of volume absorption and bicarbonate absorption were again measured starting at 1 $\mathrm{h}$ and $3 \mathrm{~h}$ after the addition of bath used in the experimental period. To examine if mineralocorticoids affected PCT transport, $10^{-6} \mathrm{M}$ aldosterone was added to the bathing solution after the control period. In studies designed to examine if the direct effect of $10^{-5} \mathrm{M}$ dexamethasone was dependent on RNA and protein synthesis, $10^{-7} \mathrm{M}$ actinomycin $\mathrm{D}$ and $5 \mu \mathrm{g} / \mathrm{ml}$ cycloheximide were used. In these studies cycloheximide was added to the bath in the experimental period with $10^{-5} \mathrm{M}$ dexamethasone. Actinomycin D was added after the control period, but $20 \mathrm{~min}$ before the addition of $10^{-5} \mathrm{M}$ dexamethasone. Measurements of volume absorption, bicarbonate absorption, and PD were performed starting 1 and $3 \mathrm{~h}$ after the addition of $10^{-5} \mathrm{M}$ dexamethasone. To examine if $10^{-7} \mathrm{M}$ actinomycin D or $5 \mu \mathrm{g} / \mathrm{ml}$ cycloheximide had an effect on transport, studies were carried out with these agents without dexamethasone.

There were at least three measurements of each parameter for each tubule. The mean values for total $\mathrm{CO}_{2}$ flux, net volume absorption, and transepithelial potential difference in a given tubule were determined. Data are means \pm SE for the tubules in a group. The Student's $t$ test for paired and unpaired data and analysis of variance were used to determine statistical significance.

\section{Results}

The first group of experiments was designed to examine if glucocorticoids administered to animals affected blood and urine $\mathrm{pH}$ and bicarbonate concentration. There was no difference between untreated and vehicle-treated control animals, so the results were combined. As shown in Table I, there was no difference in blood $\mathrm{pH}$ and blood bicarbonate concentration in control rabbits and dexamethasone treated rabbits. The urine $\mathrm{pH}$ and urine bicarbonate concentration in control animals was $8.12 \pm 0.06$ and $203.4 \pm 23.0 \mathrm{meq} / \mathrm{liter}$, respectively. The urine $\mathrm{pH}$ and urine bicarbonate concentration in dexamethasone-treated animals were $7.64 \pm 0.24$ and $104.7 \pm 24.9 \mathrm{meq} /$

Table I. Effect of Dexamethasone on Blood and Urine pH and Bicarbonate Concentration

\begin{tabular}{lcccc}
\hline & Blood $\mathrm{pH}$ & Blood $\left[\mathrm{HCO}_{3}^{-}\right]$ & Urine $\mathrm{pH}$ & Urine $\left[\mathrm{HCO}_{3}^{-}\right]$ \\
\hline \multirow{5}{*}{ meq/liter } & & meq/liter \\
Control & $7.41 \pm 0.01$ & $23.7 \pm 0.6$ & $8.12 \pm 0.06$ & $203.4 \pm 23.0$ \\
& $(n=17)$ & $(n=17)$ & $(n=13)$ & $(n=13)$ \\
Dexamethasone & $7.40 \pm 0.01$ & $23.9 \pm 0.8$ & $7.64 \pm 0.24$ & $104.2 \pm 24.9$ \\
& $(n=9)$ & $(n=9)$ & $(n=8)$ & $(n=8)$ \\
$P=$ & $\mathrm{NS}$ & $\mathrm{NS}$ & $<0.05$ & $<0.05$ \\
& & & & \\
\hline
\end{tabular}
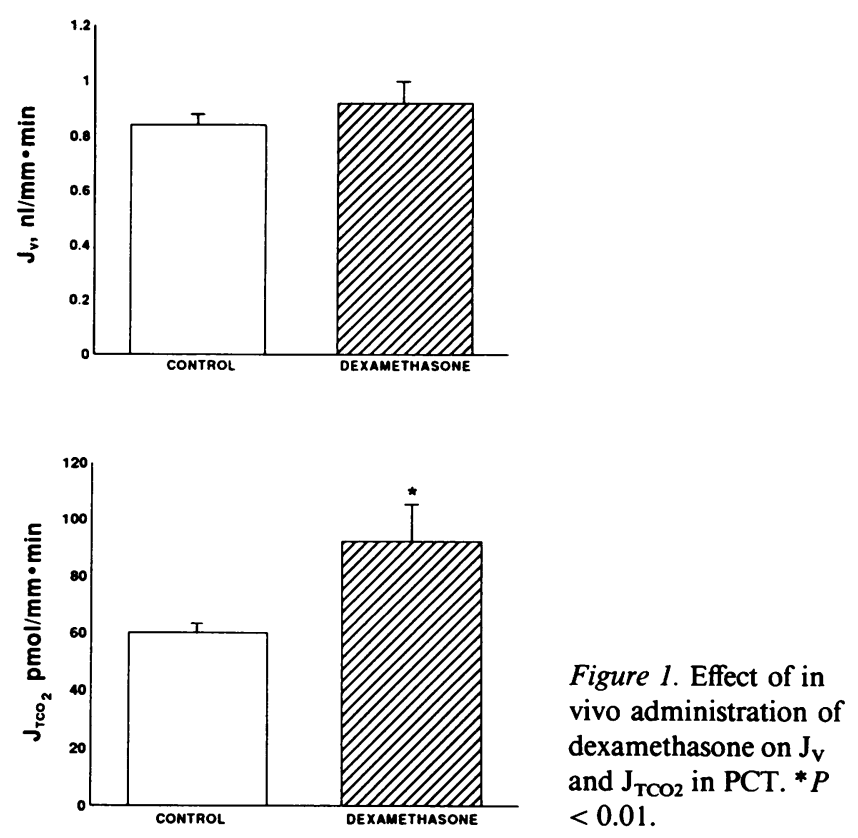

liter, respectively (both $P<0.05$ ). Thus, in vivo administration of pharmacologic doses of dexamethasone significantly decreased urine $\mathrm{pH}$ and bicarbonate concentration.

PCT from control and dexamethasone treated animals were next studied in vitro. There was no significant difference between vehicle-treated control animals and the untreated controls used in this study and they were again combined. The mean PD in control animals was $-4.6 \pm 0.3 \mathrm{mV}(n=53)$, which was not different than the $-4.0 \pm 0.6 \mathrm{mV}(n=8)$ measured in the dexamethasone-treated group. The rate of volume absorption and bicarbonate absorption measured in control $(n$ $=57)$ and dexamethasone-treated animals $(n=8)$ are shown in Fig. 1. There was not a significant difference in the rate of volume absorption in control animals $(0.82 \pm 0.04 \mathrm{nl} /$ $\mathrm{mm} \cdot \mathrm{min})$ and dexamethasone-treated animals $(0.92 \pm 0.08$ $\mathrm{nl} / \mathrm{mm} \cdot \mathrm{min})$. However, the rate of bicarbonate absorption in the dexamethasone group was $92.0 \pm 13.3 \mathrm{pmol} / \mathrm{mm} \cdot \mathrm{min}$, which was significantly greater than the $59.9 \pm 3.2 \mathrm{pmol} /$ $\mathrm{mm} \cdot \mathrm{min}$ measured in the control group $(P<0.01)$.

The systemic effect of glucocorticoids could be mediated indirectly by other hormones or by hemodynamic effects. To determine directly if glucocorticoids or mineralocorticoids affect proximal tubular transport, either dexamethasone or aldosterone was added to the bathing solution after the control period. The results are shown in Table II and Fig. 2. As previously demonstrated in our laboratory and other laboratories $(13,14)$, there is a tendency for the PD to increase with time. This was comparable in all groups studied $(P=N S)$. There was no significant difference in the rate of volume absorption or bicarbonate absorption in the time control, with $10^{-6} \mathrm{M}$ aldosterone and with $10^{-7} \mathrm{M}$ dexamethasone. After $3 \mathrm{~h}$ of incubation with $10^{-6} \mathrm{M}$ dexamethasone there was an increase in bicarbonate absorption from $57.6 \pm 6.3$ to $76.0 \pm 9.4 \mathrm{pmol} /$ $\mathrm{mm} \cdot \min (P<0.05)$. There was a comparable increase in bicarbonate absorption after $3 \mathrm{~h}$ of incubation with $10^{-5} \mathrm{M}$ dexamethasone from $48.9 \pm 6.8$ to $61.3 \pm 8.1 \mathrm{pmol} / \mathrm{mm} \cdot \mathrm{min}$ $(P<0.05)$. There was also an increase in volume absorption noted at $3 \mathrm{~h}$ at $10^{-5} \mathrm{M}$ dexamethasone from $0.72 \pm 0.08 \mathrm{nl} /$ 
Table II. Effects of Dexamethasone and Aldosterone on Proximal Convoluted Tubule Transport

\begin{tabular}{|c|c|c|c|c|c|c|c|c|c|c|}
\hline \multirow{3}{*}{$\begin{array}{l}\text { Experimental } \\
\text { protocol }\end{array}$} & \multirow[b]{3}{*}{$n$} & \multicolumn{3}{|c|}{$\mathrm{PD}, \mathrm{mV}$} & \multicolumn{3}{|c|}{$\mathrm{J}_{\mathrm{v} 2} \mathrm{nl} / \mathrm{mm} \cdot \min$} & \multicolumn{3}{|c|}{$\mathrm{J}_{\mathrm{TCO} 2} \mathrm{pmol} / \mathrm{mm} \cdot \min$} \\
\hline & & \multirow[b]{2}{*}{ Control } & \multicolumn{2}{|c|}{ Experimental } & \multirow[b]{2}{*}{ Control } & \multicolumn{2}{|c|}{ Experimental } & \multirow[b]{2}{*}{ Control } & \multicolumn{2}{|c|}{ Experimental } \\
\hline & & & $1 \mathrm{~h}$ & $3 \mathrm{~h}$ & & $1 \mathrm{~h}$ & $3 \mathrm{~h}$ & & $1 \mathrm{~h}$ & $3 \mathrm{~h}$ \\
\hline $\begin{array}{l}\text { Time control } \\
10^{-6} \mathrm{M}\end{array}$ & 6 & $-4.3 \pm 0.5$ & $-4.8 \pm 0.6^{*}$ & $-5.3 \pm 0.9^{\ddagger}$ & $0.81 \pm 0.13$ & $0.83 \pm 0.12$ & $0.83 \pm 0.12$ & $63.7 \pm 6.6$ & $66.1 \pm 8.4$ & $69.3 \pm 8.5$ \\
\hline $\begin{array}{l}\text { Aldosterone } \\
10^{-7} \mathrm{M}\end{array}$ & 5 & $-4.4 \pm 0.6$ & $-5.3 \pm 0.6^{*}$ & $-5.5 \pm 0.7^{*}$ & $0.73 \pm 0.09$ & $0.79 \pm 0.09$ & $0.76 \pm 0.06$ & $61.5 \pm 7.9$ & $64.5 \pm 8.5$ & $62.7 \pm 7.3$ \\
\hline $\begin{array}{l}\text { Dexamethasone } \\
10^{-6} \mathrm{M}\end{array}$ & 6 & $-2.8 \pm 0.7$ & $-3.2 \pm 0.13$ & $-3.1 \pm 1.0$ & $1.04 \pm 0.22$ & $1.08 \pm 0.24$ & $1.02 \pm 0.23$ & $89.2 \pm 20.3$ & $93.9 \pm 22.1$ & $95.3 \pm 20.8$ \\
\hline $\begin{array}{l}\text { Dexamethasone } \\
10^{-5} \mathrm{M}\end{array}$ & 6 & $-4.2 \pm 0.8$ & $-4.7 \pm 0.8^{\S}$ & $-5.5 \pm 0.9^{\S}$ & $0.88 \pm 0.07$ & $0.92 \pm 0.09$ & $1.01 \pm 0.12$ & $57.6 \pm 6.3$ & $62.5 \pm 7.9$ & $76.0 \pm 9.4^{*}$ \\
\hline Dexamethasone & 7 & $-4.6 \pm 0.2$ & $-5.0 \pm 0.03^{\ddagger}$ & $6.4 \pm 0.04^{*}$ & $0.72 \pm 0.08$ & $0.85 \pm 0.07^{\S}$ & $0.91 \pm 0.08^{\S}$ & $48.9 \pm 6.8$ & $58.6 \pm 7.7^{*}$ & $61.3 \pm 8.1^{*}$ \\
\hline
\end{tabular}

${ }^{*} P<0.05$ vs control period. ${ }^{\ddagger} 0.05<P \leq 0.10$ vs control period. ${ }^{\S} P<0.01$ vs control period.

$\mathrm{mm} \cdot \min$ to $0.91 \pm 0.08 \mathrm{nl} / \mathrm{mm} \cdot \min (P<0.01)$. A significant increase in bicarbonate and volume absorption was also measured $1 \mathrm{~h}$ after addition of $10^{-5} \mathrm{M}$ dexamethasone.

The final series of experiments examined if the effect of $10^{-5} \mathrm{M}$ dexamethasone to stimulate bicarbonate absorption required RNA and protein synthesis. In these studies $10^{-7} \mathrm{M}$ actinomycin D and $5 \mu \mathrm{g} / \mathrm{ml}$ of cycloheximide were added to the bathing solution after the control period. The results are shown in Table III. There was no significant change in the PD and the rate bicarbonate and volume absorption in tubules treated with actinomycin $\mathrm{D}$. The increase in bicarbonate absorption with $10^{-5} \mathrm{M}$ dexamethasone was not observed in the presence of actinomycin D. Cycloheximide produced a small decrease in volume absorption after $3 \mathrm{~h}$ of incubation, but there was no significant effect on bicarbonate absorption and PD. Interestingly there was a small but significant decrease in volume absorption and bicarbonate absorption in tubules in- cubated with $10^{-5} \mathrm{M}$ dexamethasone and cycloheximide. These results are consistent with a requirement for RNA and protein synthesis for the effect of dexamethasone on proximal tubular acidification.

\section{Discussion}

The present in vitro microperfusion study examined whether glucocorticoids affect proximal tubule bicarbonate transport. In vivo administration of pharmacologic doses of dexamethasone resulted in a significant decrease in urinary bicarbonate concentration and urine $\mathrm{pH}$, and in a 50\% stimulation in proximal convoluted tubule bicarbonate reabsorption in comparison to control animals. Furthermore, in paired in vitro studies $10^{-6} \mathrm{M}$ and $10^{-5} \mathrm{M}$ dexamethasone, but not aldosterone, resulted in a stimulation in bicarbonate absorption. This effect was inhibited by cycloheximide and actinomycin D. These

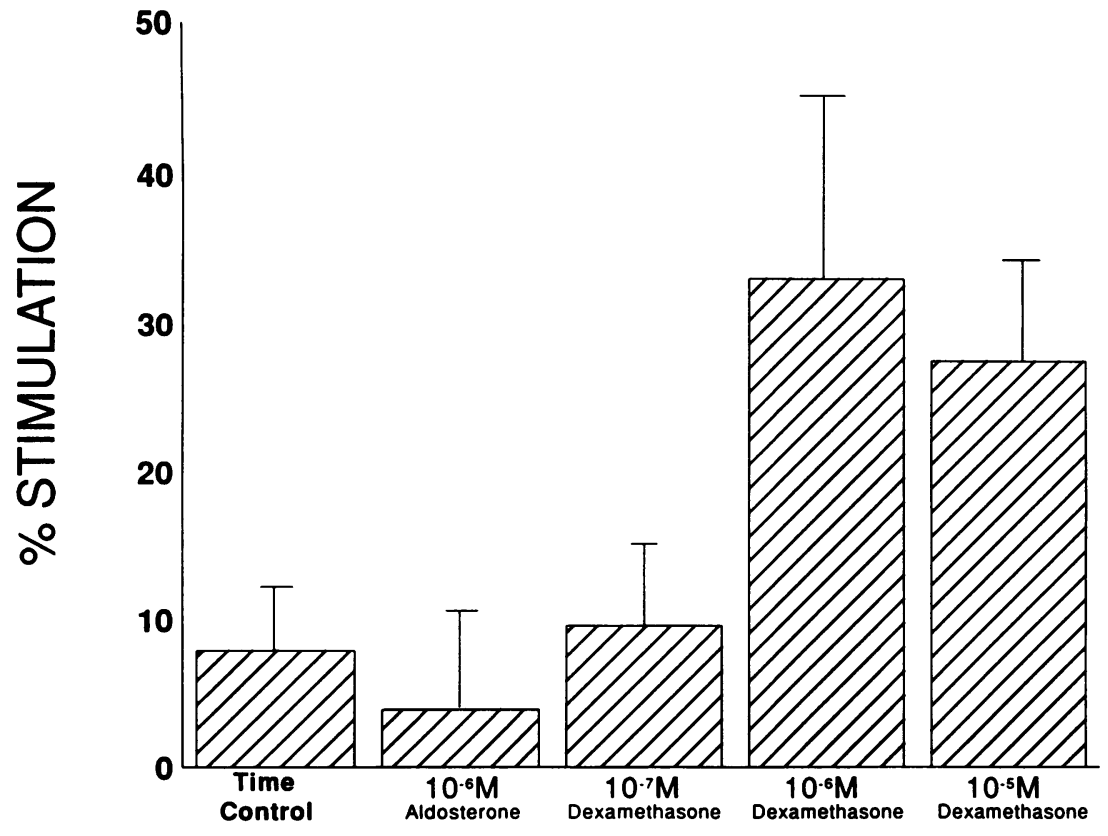

Figure 2. Percent stimulation in bicarbonate absorption when compared to the control period after $3 \mathrm{~h}$ of incubation with vehicle or hormone. 
Table III. Effect of Actinomycin D and Cycloheximide on Proximal Convoluted Tubule Transport in the Presence and Absence of $10^{-5} \mathrm{M}$ Dexamethasone

\begin{tabular}{|c|c|c|c|c|c|c|c|c|c|c|}
\hline \multirow{3}{*}{$\begin{array}{l}\text { Experimental } \\
\text { protocol }\end{array}$} & \multirow[b]{3}{*}{$n$} & \multicolumn{3}{|c|}{$\mathrm{PD}, \mathrm{mV}$} & \multicolumn{3}{|c|}{$\mathrm{J}_{\mathrm{v} 2} \mathrm{nl} / \mathrm{mm} \cdot \min$} & \multicolumn{3}{|c|}{$\mathrm{J}_{\mathrm{TCO} 2} \mathrm{pmol} / \mathrm{mm} \cdot \min$} \\
\hline & & \multirow[b]{2}{*}{ Control } & \multicolumn{2}{|c|}{ Experimental } & \multirow[b]{2}{*}{ Control } & \multicolumn{2}{|c|}{ Experimental } & \multirow[b]{2}{*}{ Control } & \multicolumn{2}{|c|}{ Experimental } \\
\hline & & & $1 \mathrm{~h}$ & $3 \mathrm{~h}$ & & $1 \mathrm{~h}$ & $3 \mathrm{~h}$ & & $1 \mathrm{~h}$ & $3 \mathrm{~h}$ \\
\hline \multicolumn{11}{|l|}{$10^{-7} \mathrm{M}$} \\
\hline $\begin{array}{l}\text { Actinomycin D } \\
10^{-7} \mathrm{M} \\
\text { Actinomycin D } \\
+10^{-5} \mathrm{M}\end{array}$ & 6 & $-5.3 \pm 1.1$ & $-5.6 \pm 1.1$ & $-5.6 \pm 1.1$ & $0.90 \pm 0.07$ & $0.88 \pm 0.08$ & $0.85 \pm 0.06$ & $55.6 \pm 4.8$ & $53.4 \pm 5.9$ & $53.5 \pm 5.3$ \\
\hline $\begin{array}{l}\text { Dexamethasone } \\
5 \mu \mathrm{g} / \mathrm{ml}\end{array}$ & 6 & $-5.3 \pm 0.4$ & $-5.2 \pm 0.4$ & $-4.6 \pm 0.3$ & $0.76 \pm 0.10$ & $0.75 \pm 0.09$ & $0.71 \pm 0.08$ & $55.6 \pm 9.2$ & $51.7 \pm 7.8$ & $46.8 \pm 7.0$ \\
\hline $\begin{array}{l}\text { Cycloheximide } \\
5 \mu \mathrm{g} / \mathrm{ml} \\
\text { Cycloheximide } \\
+10^{-5} \mathrm{M}\end{array}$ & 5 & $-6.5 \pm 0.5$ & $-5.9 \pm 0.2$ & $-6.1 \pm 0.2$ & $1.00 \pm 0.13$ & $0.88 \pm 0.06$ & $0.83 \pm 0.09^{*}$ & $58.4 \pm 5.5$ & $52.8 \pm 5.4$ & $52.6 \pm 6.6$ \\
\hline Dexamethasone & 5 & $-5.4 \pm 1.0$ & $-5.0 \pm 1.0^{*}$ & $-4.9 \pm 1.0$ & $0.93 \pm 0.13$ & $0.82 \pm 0.08$ & $0.74 \pm 0.08^{\ddagger}$ & $64.6 \pm 7.5$ & $56.3 \pm 4.8^{*}$ & $53.2 \pm 0.05^{\ddagger}$ \\
\hline
\end{tabular}

${ }^{*} 0.05<P<0.1$ vs control period. ${ }^{\ddagger} P<0.05$ vs control period.

data demonstrate that glucocorticoids stimulate bicarbonate transport in the proximal convoluted tubule, and that the effect is dependent on protein synthesis.

The above results suggest that glucocorticoid receptors would be involved in signal transduction; however, there is conflicting evidence for the presence of glucocorticoid receptors in the proximal convoluted tubule. Nuclear and cytoplasmic glucocorticoid receptors have been demonstrated in cortical tubular suspensions which contain $>85 \%$ proximal tubules (15). While the above studies conclude that there are proximal tubule glucocorticoid receptors, these studies were performed in tubule preparations enriched for proximal tubules, but containing other segments. Recent studies have questioned the presence of glucocorticoid receptors in proximal tubules ( 16 , 17). Dexamethasone-binding studies in dissected rabbit nephron segments were examined after incubation of renal pyramids or after in vivo injection of $\left[{ }^{3} \mathrm{H}\right]$ dexamethasone using autoradiography (16). Nuclear binding was observed in all segments beyond the proximal tubule. Cytoplasmic binding of $\left[{ }^{3} \mathrm{H}\right]$ dexamethasone was present in the proximal tubule. In addition, this group did not detect proximal tubular glucocorticoid receptors using immunostaining with monoclonal antiglucocorticoid receptor antibody (17). Glucocorticoid receptors were detected in distal nephrons using this method. While these studies suggest that glucocorticoids use a different receptor or have a non-receptor-mediated effect on the proximal tubule, mRNA for the glucocorticoid receptor has recently been detected in several nephron segments including the proximal tubule (18).

In this study systemic administration of pharmacologic doses of dexamethasone did not change blood $\mathrm{pH}$ or bicarbonate concentration. The urine $\mathrm{pH}$ and bicarbonate concentration were significantly lower in the dexamethasone treated animals. While these data are consistent with a stimulation of renal acidification, there are a number of other potential variables which could account for these results. The rabbits were not pair fed and the quantity of base-producing chow consumed could have been different. Dexamethasone could also have influenced gastrointestinal absorption of the base in the chow. In addition, glucocorticoids stimulate endogenous acid production which would result in greater acid excretion leading to a lower urine $\mathrm{pH}$ and bicarbonate concentration.

Previous studies have examined the effect of in vivo administration of glucocorticoids on renal $\mathrm{Na}^{+} / \mathrm{H}^{+}$antiporter activity studied in vitro $(10,11)$. Administration of the same dose of subcutaneous dexamethasone as in the present study resulted in a $70 \%$ increase in $\mathrm{Na}^{+} / \mathrm{H}^{+}$antiporter activity (10). This result compares well with the increase in bicarbonate absorption noted in our study. While these results do not directly demonstrate an effect of glucocorticoids on the proximal tubule epithelium, they do show that systemic glucocorticoids can have profound effects on proximal tubule acidification. However, our study only examined the effect of pharmacologic doses of glucocorticoids on proximal convoluted tubule acidification in glucocorticoid replete animals. We did not compare proximal tubule acidification in glucocorticoid deficient animals to glucocorticoid replete animals.

Previous studies have suggested that glucocorticoids may be important in maturation of proximal tubule transport. Triamcinolone binding to a proximal tubule suspension (85$90 \%$ proximal tubules) was significantly greater in 20-d old (young) than in 40-d old (adult) Sprague-Dawley rats (19). This group also examined the effect of pharmacologic doses of glucocorticoids on volume absorption using the split droplet technique and proximal tubule NaKATPase activity (20). Glucocorticoids had no effect on volume absorption and $\mathrm{NaK}$ ATPase activity in adult animals, but caused a significant increase in young rats. We have previously examined the effect of subcutaneous administration of $60 \mu \mathrm{g} / \mathrm{kg}$ of dexamethasone administered daily to pregnant does $3 \mathrm{~d}$ before their expected date of delivery. This small dose of glucocorticoids produced a significant increase in volume absorption, PD, and bicarbonate transport in dexamethasone treated as compared to control neonates (21). There was also a small, but not significant, increase in glucose transport in neonates studied within $48 \mathrm{~h}$ of birth. The above studies are consistent with glucocorticoids increasing proximal tubular transport by stimulating the $\mathrm{Na}$ KATPase and suggest that glucocorticoids may act by stimulating the NaKATPase in neonatal proximal tubules. In the present study, a significantly greater dose of dexamethasone ad- 
ministered to adult rabbits produced a large increase in bicarbonate absorption as compared to controls, but there was no significant effect on the transepithelial potential difference or on volume absorption. Thus, in adult animals, glucocorticoids may have a more selective action on proximal tubule bicarbonate absorption, perhaps by selective stimulation of the $\mathrm{Na}^{+} / \mathrm{H}^{+}$antiporter $(10,11)$.

The above studies are consistent with a direct effect of glucocorticoids on the proximal tubule, but do not exclude indirect effects of glucocorticoids via changes in other systemic hormones or hemodynamic changes. Recent studies have provided evidence for a direct effect of glucocorticoids on chick renal epithelial cells (22). Dexamethasone inhibited phosphate uptake in primary cultured renal epithelial cells. This effect is observed within $4 \mathrm{~h}$ after addition of dexamethasone and maximal inhibition occurred at $18 \mathrm{~h}$. The effect was dose dependent with a small inhibition (13\%) at $10^{-7} \mathrm{M}$ and maximal inhibition at $10^{-6} \mathrm{M}$ dexamethasone. The dexamethasone induced inhibition was blocked by actinomycin D and cycloheximide. These results are in good agreement with the dose and time course of our studies, though it was not technically possible to examine the effect of dexamethasone in isolated and perfused proximal tubules for longer than $4 \mathrm{~h}$.

There is also evidence for a direct effect of glucocorticoids on mammalian renal cells. In a single cell preparation consisting mainly of proximal tubule cells from New Zealand White Rabbits, dexamethasone inhibited sodium-dependent phosphate transport in a dose dependent manner (23). This group has also examined the effect of dexamethasone on $\mathrm{Na}^{+} / \mathrm{H}^{+}$ antiporter activity. Within $1 \mathrm{~h}$ of addition of $10^{-7} \mathrm{M}$ dexamethasone there was an increase in $\mathrm{Na}^{+} / \mathrm{H}^{+}$antiporter activity (24). The stimulation by dexamethasone was not observed in the presence of actinomycin D or cycloheximide. In these studies the effect of dexamethasone was dose dependent and occurred at $10^{-9} \mathrm{M}$, though greater stimulation occurred with $10^{-6} \mathrm{M}$ dexamethasone. This difference in dose response between this study and our own may be caused by a greater sensitivity to detect a change in $\mathrm{Na}^{+} / \mathrm{H}^{+}$antiporter activity than on whole tubule bicarbonate absorption. However, these studies used a cell suspension that contained cells other than proximal tubule cells, which could respond to dexamethasone at lower concentrations.

The present in vitro microperfusion study examined the effect of dexamethasone on proximal convoluted tubule bicarbonate transport. In vivo administration of pharmacologic doses of dexamethasone resulted in an increase in bicarbonate absorption in isolated proximal convoluted tubules. Incubation of proximal tubules with $10^{-6} \mathrm{M}$ and $10^{-5} \mathrm{M}$ dexamethasone resulted in a direct stimulation in bicarbonate reabsorption within $3 \mathrm{~h}$ of incubation, which was dependent on RNA and protein synthesis. This study did not address whether lower concentrations of dexamethasone over longer periods of incubation could have stimulated bicarbonate transport. Thus, the physiologic importance of glucocorticoids to modulate proximal tubule bicarbonate reabsorption remains an important unresolved issue. This study, however, directly demonstrated that pharmacologic concentrations of glucocorticoids stimulate proximal tubule bicarbonate reabsorption.

\section{Acknowledgments}

We are grateful for the technical assistance of Rebecca Aricheta and the able secretarial assistance of Mrs. Janell McQuinn.
This work was supported by National Institutes of Health Grant DK 41612.

\section{References}

1. Hulter, H. N., J. H. Licht, E. L. Bonner, Jr., R. D. Glynn, and A. Sebastian. 1980. Effects of glucocorticoid steroids on renal and systemic acid-base metabolism. Am. J. Physiol. 239 (Renal Fluid Electrolyte Physiol. 8): F30-F43.

2. Hulter, H. N., J. F. Sigala, and A. Sebastian. 1981. Effects of dexamethasone on renal and systemic acid-base metabolism. Kidney Int. 20:43-39.

3. Welbourne, T. C., P. Phenix, C. Thornley-Brown, and C. J. Welbourne. 1976. Triamcinolone activation of renal ammonia production (39587). Proc. Soc. Exp. Biol. Med. 153:539-542.

4. Sapir, D. G., T. Pozefsky, J. P. Knochel, and M. Walser. 1977. The role of alanine and glutamine in steroid-induced nitrogen wasting in man. Clin. Sci. (Lond.). 53:215-220.

5. Wilcox, C. S., D. A. Cemerikic, and G. Giebisch. 1982. Differential effects of acute mineralo- and glucocorticosteroid administration on renal acid elimination. Kidney Int. 21:546-556.

6. Dubrovsky, A. H. E., R. C. Nair, M. K. Byers, and D. Z. Levine. 1981 Renal net acid excretion in the adrenalectomized rat. Kidney Int. 19:516-528.

7. Sartorius, O. W., D. Calhoon, and R. F. Pitts. 1952. The capacity of the adrenalectomized rat to secrete hydrogen and ammonium ions. Endocrinology. 51:444-450.

8. Kinsella, J., T. Cujdik, and B. Sacktor. 1984. $\mathrm{Na}^{+} / \mathrm{H}^{+}$exchange activity in renal brush border membrane vesicles in response to metabolic acidosis: the role of glucocorticoids. Proc. Natl. Acad. Sci. USA. 81:630-634.

9. Murer, H., U. Hopfer, and R. Kinne. 1976. Sodium/proton antiporter in brush-border membrane vesicles isolated from rat small intestine and kidney. Biochem. J. 154:597-604.

10. Freiberg, J. M., J. Kinsella, and B. Sacktor. 1982. Glucocorticoids increase the $\mathrm{Na}^{+}-\mathrm{H}^{+}$exchange and decrease the $\mathrm{Na}^{+}$gradient-dependent phosphate-uptake systems in renal brush border membrane vesicles. Proc. Natl. Acad. Sci. USA. 79:4932-4936.

11. Kinsella, J. L., J. M. Freiberg, and B. Sacktor. 1985. Glucocorticoid activation of $\mathrm{Na}^{+} / \mathrm{H}^{+}$exchange in renal brush border vesicles: kinetic effects. $A m$. J. Physiol. 248 (Renal Fluid Electrolyte Physiol. 17): F233-F239.

12. Burg, M. B., J. Grantham, M. Abramow, and J. Orloff. 1966. Preparation and study of fragments of single rabbit nephrons. Am. J. Physiol. 210:1293-1298.

13. Quigley, R., and M. Baum. 1991. Effects of growth hormone and insulinlike growth factor I on rabbit proximal convoluted tubule transport. J. Clin. Invest. 88:368-374.

14. Schuster, V. L., J. P. Kokko, and H. R. Jacobson. 1984. Angiotensin II directly stimulates sodium transport in rabbit proximal convoluted tubules. $J$. Clin. Invest. 73:507-515.

15. Takao, M., D. W. Scholer, and I. S. Edelman. 1981. Glucocorticoid receptors in rat kidney cortical tubules enriched in proximal and distal segments. $\mathrm{Am}$. J. Physiol. 240 (Renal Fluid Electrolyte Physiol. 9): F38-F45.

16. Farman, N., A. Vandewalle, and J. P. Bonvalet. 1983. Autoradiographic determination of dexamethasone binding sites along the rabbit nephron. Am. J. Physiol. 244 (Renal Fluid Electrolyte Physiol. 13): F325-F334.

17. Farman, N., M. E. Oblin, M. Lombes, F. Delahaye, H. M. Westphal, J. P. Bonvalet, and J. M. Gasc. 1991. Immunolocalization of gluco- and mineralocorticoid receptors in rabbit kidney. Am. J. Physiol. 260 (Cell Physiol. 29): C226C233.

18. Todd-Turla, K. M., J. P. Briggs, A. Smart, P. Killen, and J. Schnermann. 1991. Distribution of mineralocorticoid and glucocorticoid receptor mRNA along the rat kidney nephron. Am. Soc. Nephrol. 2 (Cell and Transport Physiol.): 779. (Abstr.)

19. Aperia, A., L-A. Haldosen, L. Larsson, and J.-A. Gustafsson. 1985. Ontogeny of triamcinolone-acetonide binding sites in outer cortical tissue from rat kidneys. Am. J. Physiol. 249 (Renal Fluid Electrolyte Physiol. 18): F891-F897.

20. Aperia, A., and L. Larsson. 1984. Induced development of proximal tubular NaKATPase basolateral cell membranes and fluid reabsorption. Acta Physiol. Scand. 121:133-141.

21. Baum, M., and R. Quigley. 1991. Prenatal glucocorticoids stimulate neonatal juxtamedullary proximal convoluted tubule acidification. Am. J. Physiol. 261 (Renal Fluid Electrolyte Physiol. 30): F746-F752.

22. Noronha-Blob, L., and B. Sacktor. 1986. Inhibition by glucocorticoids of phosphate transport in primary cultured renal cells. J. Biol. Chem. 261:21642169.

23. Poujeol, P., and A. Vandewalle. 1985. Phosphate uptake by proximal cells isolated from rabbit kidney: role of dexamethasone. Am. J. Physiol. 249 (Renal Fluid Electrolyte Physiol. 18): F74-F83.

24. Bidet, M., J. Merot, M. Tauc, and P. Poujeol. 1987. $\mathrm{Na}^{+} / \mathrm{H}^{+}$exchanger in proximal cells isolated from kidney. II. Short-term regulation by glucocorticoids. Am. J. Physiol. 253 (Renal Fluid Electrolyte Physiol. 22): F945-F951. 